\title{
Performance consequences of food mixing in two passion vine leaf-footed bugs, Holymenia clavigera (Herbst, 1784) and Anisoscelis foliacea marginella (Dallas, 1852) (Hemiptera; Coreidae)
}

\author{
Rodrigues, D. ${ }^{\text {a* }}$, Duarte, LS. ${ }^{\mathrm{b}}$ and Moreira, GRP., ${ }^{\mathrm{a}, \mathrm{b}}$
}

\author{
aPrograma de Pós-Graduação em Biologia Animal, Departamento de Zoologia, \\ Instituto de Biociências, Universidade Federal do Rio Grande do Sul - UFRGS, \\ Av. Bento Gonçalves, 9500, Bloco IV, Prédio 43435, CEP 91501-970, Porto Alegre, RS, Brazil \\ 'Programa de Pós-Graduação em Ecologia, Instituto de Biociências, Universidade Federal do Rio Grande do Sul - UFRGS, \\ Av. Bento Gonçalves, 9500, Bloco IV, Prédio 43435, CEP 91501-970, Porto Alegre, RS, Brazil \\ *e-mail: dani_rodrig@yahoo.com.br
}

Received September 27, 2005 - Accepted October 11, 2005 - Distributed February 28, 2007

(With 4 figures)

\begin{abstract}
Holymenia clavigera (Herbst) and Anisoscelis foliacea marginella (Dallas) (Hemiptera: Coreidae: Anisoscelini) are distributed in southern Brazil and use various passion vine species (Passifloraceae) as host-plants. Preliminary observations indicate a high coexistence of these species in terms of host-plant use; in addition, there is a strong similarity regarding egg and nymph morphology. In this study, the most suitable feeding sites for nymph performance on wild (Passiflora suberosa Linnaeus and Passiflora misera Humbold, Bonpland et Kunth) and cultivated (Passiflora edulis Sims) hosts were determined by rearing them on each host and on the combination of hosts. Performance was determined by evaluating nymph development and survivorship, and adult size at emergence. Plant parts used were also recorded. For both species, $P$. suberosa was the most suitable host plant. First instar nymphs of both species fed on terminal buds more frequently when compared to other plant parts. Second instar nymphs switched to green fruits, whose behavior was more pronounced for $H$. clavigera. Thus, $H$. clavigera and A. foliacea marginella immatures are extremely similar in terms of host-plant use and consequences for performance, in addition to their morphological similarity. We suggest that these coreids may have evolved through several processes, including parsimony between the immature stages after speciation, evolutionary convergence, mimicry or genetic drift.
\end{abstract}

Keywords: Coreidae, passion vines, host-plant selection, immature stages, nymph performance.

\section{Conseqüências da dieta mista na performance de dois coreídeos do maracujá, Holymenia clavigera Herbst, 1784 e Anisoscelis foliacea marginella Dallas, 1852 (Hemiptera; Coreidae)}

\begin{abstract}
Resumo
Holymenia clavigera (Herbst) e Anisoscelis foliacea marginella (Dallas) (Hemiptera: Coreidae: Anisoscelini) ocorrem no sul do Brasil e são hóspedes de diversas espécies de Passifloraceae. Observações preliminares indicam uma alta coexistência destas espécies em termos de uso da planta hospedeira; em adição, ovos e ninfas são extremamente semelhantes. Neste estudo comparou-se a performance das ninfas das duas espécies em passifloráceas nativas silvestres (Passiflora suberosa Linnaeus e Passiflora misera Humbold, Bonpland et Kunth) e cultivadas (Passiflora edulis Sims), oferecidas em separado e conjuntamente. Foram determinadas as taxas de desenvolvimento e mortalidade ninfal, bem como o tamanho do adulto à emergência. As partes das hospedeiras mais utilizadas para alimentação foram registradas. Para ambos os coreídeos, $P$. suberosa conferiu melhor performance. Ninfas de primeiro instar de ambas as espécies alimentaram-se com maior intensidade da região apical dos ramos quando comparado com as demais partes das plantas. Ambas as espécies mudaram para os frutos verdes no segundo instar, sendo este comportamento mais pronunciado em H. clavigera. Deste modo, além da semelhança morfológica, os imaturos de H. clavigera and A. foliacea marginella são extremamente similares no tangente à interação com suas plantas hospedeiras. Sugere-se que estes coreídeos possam ter evoluído através de vários processos, entre os quais parcimônia entre as fases imaturas após especiação, convergência evolutiva, mimetismo ou deriva genética.
\end{abstract}

Palavras-chave: Coreidae, maracujás, seleção da planta hospedeira, estágios imaturos, performance ninfal. 


\section{Introduction}

Performance studies are important for understanding life history traits and their dynamics. For phytophagous insects, this approach provides information related to different trophic levels (see Abrahamson and Weis, 1997; Singer et al., 2004). The outcome of the performance of a given insect may result from physical and/or chemical plant properties, or may reflect selective pressures imposed by oviposition patterns, natural enemies (see Bernays and Graham, 1988; Thompson, 1988; Abrahamson and Weis, 1997), or the evolution of insect specialization (Joshi and Thompson, 1995).

Phytophagous hemipterans are commonly not restricted to vegetative or reproductive parts of their hostplants, and sometimes studies of performance have faced difficulties to maintain the nutritional quality of vegetative parts that they require. As a consequence, most information available refers to seed sucking species, many of them of economic importance. Studies with coreids include nymph development time of nymphs feeding on plants of no economic importance [Leptoglossus gonagra (Amaral-Filho and Storti-Filho, 1976), Veneza stigma (Amaral-Filho and Cajueiro, 1977), and Crinocerus sanctus (Amaral-Filho, 1986)], or on host-plants of economic importance [Phthia picta (Amaral-Filho, 1981) Leptoglossus zonatus (Panizzi, 1989), and Anasa tristis (Bonjour and Fargo, 1989)].

Holymenia clavigera and Anisocelis foliacea marginella (Anisoscelini) are distributed in southern Brazil and use the same host-plants as feeding resources (Passifloraceae) (Schaefer and Mitchell, 1983). Some individuals were found feeding on both wild (e.g., Passiflora suberosa Linnaeus) and cultivated species (e.g., Passiflora edulis Sims) (Lima, 1940). Although nymphs of these species are morphologically very similar (Rodrigues and Moreira, 2005), their ontogenetic trajectories and adult morphology differ significantly (Rodrigues et al., 2005). Few data are found in the literature, which include notes on nymph mortality of Anisoscelis (Amaral-Filho, 1981), and of Holymenia histrio, showing high nymph mortality on different passion vine fruits (Baldin and Boiça-Júnior, 1999).

Therefore, we determined nymph performance of $H$. clavigera and A. foliacea marginella on three passion vine species native to southern Brazil (Rio Grande do Sul State - RS): P. suberosa, Passiflora misera Humbold, Bonpland et Kunth and $P$. edulis. The wild form of P. edulis is rarely found in RS State, and it is restricted to Mata Atlântica patches (northeastern RS). Both forms are, however, similar in size and shape (C. Mondin and G. R. P. Moreira, UFRGS, unpublished data). The plant parts used during the ontogeny were also recorded, since the high mobility of these species makes the use of several parts possible within a given host plant.

\section{Material and Methods}

\subsection{Insects and plants}

H. clavigera and A. foliacea marginella adults were field-collected from the Porto Alegre $\left(30^{\circ} 05^{\prime} \mathrm{S}\right.$ and $\left.51^{\circ} 10^{\prime} \mathrm{W}\right)$ and Eldorado do Sul $\left(30^{\circ} 08^{\prime} \mathrm{S}\right.$ and $51^{\circ}$ $13^{\prime}$ W) Municipalities, RS. Adults were kept in cages (20 × $20 \times 93 \mathrm{~cm} ; \mathrm{n}=12 /$ cage $)$ under controlled abiotic conditions ( 14 hours of light: 10 hours of darkness; $25 \pm 2{ }^{\circ} \mathrm{C}$ ).

$P$. suberosa and $P$. misera shoots were obtained from passion vine gardens at the Departamento de Zoologia/ UFRGS, Porto Alegre Municipality. P. edulis was obtained from a cultivation located either at the Centro de Biotecnologia/UFRGS, Porto Alegre Municipality or Estação Agronômica/UFRGS (Eldorado do Sul Municipality).

In order to avoid inducing responses and/or feeding preference, adults were fed ad libitum with shoots bearing both vegetative (stems, terminal buds and leaves) and reproductive (flower buds, open flowers, green and purple fruits) parts of P. suberosa, P. misera, and P. edulis. Shoots were placed in plastic bottles provided with $50 \mathrm{~cm}$ high, wooden frame supports $(\mathrm{n}=3 /$ bottle), and replaced when wilted. Tap water placed on Petri dishes with wet cotton was also offered to the adults. Cages were checked daily, and eggs were collected and placed on Petri dishes, lined with moist filter paper.

\subsection{Experimental design}

Freshly-hatched nymphs were randomly distributed on each host plant (= treatments: $P$. suberosa, $P$. misera, and $P$. edulis) and on the three hosts combined (mixed treatment). Immatures were fed as described for the adults, and all nymphs of a given treatment were placed in a single cage.

Nymphs $(n=20)$ were marked dorsally (thorax or abdomen) with dots by using enamel paint (Faber-Castell ${ }^{\circledR}$ ) of ten different colors: white, yellow, orange, pink, red, green, pale blue, blue, brown and black. As a result, nymphs had the following identification: nymph $\# 1$ = marked with a white dot on the thorax; nymph \#2 = marked with a white dot on the abdomen, and so on. Body structures such as wing pads and repugnatory glands were avoided in terms of painting. We knew from previous studies that nymph mortality would be high, but approximately equal among treatments during ontogeny. Thus, to make possible comparisons regarding development rate and size among treatments, nymphs were replaced in case of death; as a consequence, each cage $(=$ treatment $)$ had approximately twenty nymphs throughout the experiment.

Nymphs were observed daily. Nymph development and survivorship, and adult size at emergence (the body length, from tylus to the last abdominal segment) were recorded. Plant parts used during the ontogeny were also recorded twice a day ( 9 and 15 hours), and each observation lasted 30 minutes. When nymphs were reared in the mixed treatment, it was recorded whether the same individual had used different plant parts.

\subsection{Statistical analysis}

First, development time and adult size were analyzed separately. The normality and homocedasticity of vari- 
ances were evaluated using Kolmogorov-Smirnov's and Bartlett's tests, respectively (Sokal and Rohlf, 1995). One-way ANOVAs were used and, in case of a significant difference, treatments were submitted to TukeyKramer's (in case of homocedasticity) or Dunn's (in case of heterocedasticity) multiple comparison tests. All tests were performed using an alpha $=0.05$, on GraphPad Prism ${ }^{\circledR}$ software (Motulsky, 1999).

Secondly, performance was treated as a multidimensional factor that considers all life history traits here recorded - nymph survivorship, development time, and size at emergence (sensus Thompson, 1988). The effects of treatment and coreid species on nymph survivorship (a qualitative variable) using ANOVA with Randomization Testing (1000 iteractions) (Manly, 1991) were evaluated. Then, the effects of treatment, coreid species and sex on development time and size (quantitative variables) were evaluated only for the individuals that reached the adult stage (ANOVA with Randomization Testing; 1000 interactions). Both tests were run after calculating a Euclidean distance matrix between groups of sampling units, using MULTIV $^{\circledR}$ software (Pillar, 2001).

\section{Results}

\subsection{Nymph survivorship}

Less than $50 \%$ of the nymphs of $H$. clavigera and A. foliacea marginella survived until the adult stage in all treatments (Figure 1a). Effects on nymph survivorship were not significant regarding either treatment or coreid species (Table 1).

\subsection{Nymph development time}

$H$. clavigera nymphs grew significantly faster when reared on $P$. suberosa than on $P$. misera (Dunn's multiple comparison tests, $\mathrm{p}<0.05$ ), and on $P$. edulis (Dunn's multiple comparison tests, $\mathrm{p}<0.001)$. Nymphs reared on $P$. edulis grew significantly slower than those reared on all passion vines together (Dunn's multiple comparison tests, $\mathrm{p}<0.01)$.

For A. foliacea, $P$. suberosa provided a significant faster development time than P. edulis (Tukey-Kramer's multiple comparison tests, $\mathrm{p}<0.05)$. Nymphs reared on $P$. edulis also had a significant longer development time than all passion vines together (Tukey-Kramer's multiple comparison tests, c <0.05) (Figure 1b).

\subsection{Adult size}

For $H$. clavigera, nymphs were significantly larger when they fed on P. suberosa than on P. misera (Dunn's multiple comparison tests, $\mathrm{p}<0.01$ ), and on all passion vines together (Dunn's multiple comparison tests, $\mathrm{p}<0.05)$.

For A. foliacea marginella, adult size was not significantly different among treatments (ANOVA, $\mathrm{p}=0.8892$ ) (Figure 1c).

\subsection{Performance}

For both coreids, there was a treatment effect on nymph performance (Table 2). $P$. suberosa provided a su-
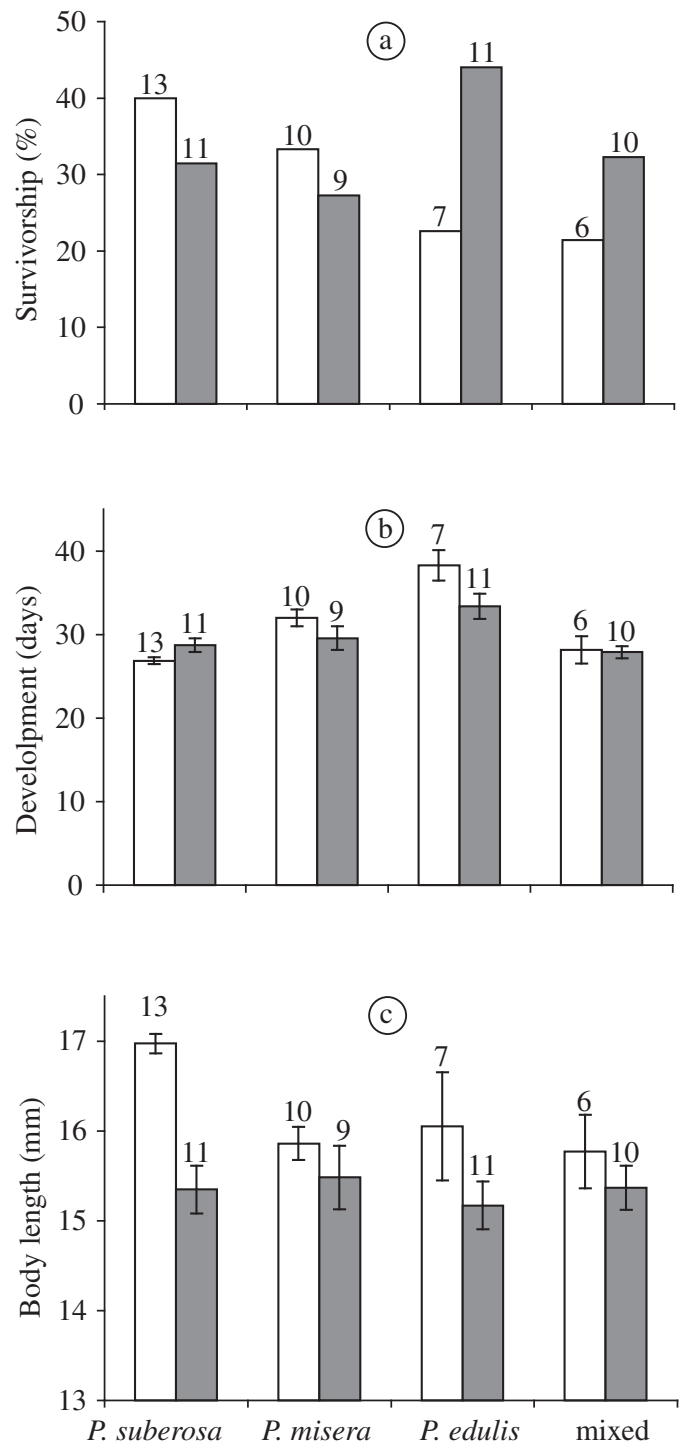

Treatment

Figure 1. Nymph survivorship a), development time b), and adult size c) of $H$. clavigera (open bars) and $A$. foliacea marginella (closed bars) (mean + standard error) reared on different passion vines alone and in combination (= treatments). Arabic numbers above bars indicate the total number of adults obtained per treatment.

perior performance than $P$. misera and $P$. edulis. Nymphs reared on $P$. edulis had significant poorer performances when compared to the other treatments. There was no effect of coreid species and sex on nymph performance (Table 2).

\subsection{Use of plant parts}

For both coreids, a progressive use of reproductive structures of all passion vines as nymphs developed was detected (Figures 2, 3 and 4). Fruit feeding was less pro- 
Table 1. ANOVA with Randomization Testing (1000 iteractions) of the effects of treatment and coreid species on nymph survivorship of $H$. clavigera and A. foliacea marginella.

\begin{tabular}{cllcc}
\hline \multicolumn{2}{c}{ Source of variation } & Comparison & Sum of squares & P \\
\hline Treatment & between groups & & 0.22382 & 0.798 \\
& P. suberosa & P. misera & 0.086244 & 0.562 \\
& P. suberosa & P. edulis & 0.030496 & 0.715 \\
& P. suberosa & mixed & 0.211115 & 0.327 \\
& P. misera & P. edulis & 0.011671 & 0.829 \\
& P. misera & mixed & 0.028158 & 0.727 \\
& P. edulis & mixed & 0.072523 & 0.630 \\
\hline Coreid species & between groups & 0.077776 & 0.575 \\
& H. clavigera & A. foliacea & 0.077776 & 0.575 \\
\hline Interaction & coreid apecies x treatment & & 0.89518 & 0.252 \\
\hline
\end{tabular}

Table 2. ANOVA with Randomization Testing (1000 interactions) of the effects of treatment, coreid species and sex on nymph performance of $\mathrm{H}$. clavigera and A. foliacea marginella. Asterisks indicate significant differences between sources of variation and their corresponding comparisons.

\begin{tabular}{lllll}
\hline \multicolumn{2}{c}{ Source of variation } & Comparison & Sum of squares & P \\
\hline Treatment & between groups & & 0.00013304 & $0.0001^{*}$ \\
& P. suberosa & P. misera & $2.1263^{-05}$ & $0.0273^{*}$ \\
& P. suberosa & P. edulis & 0.00011175 & $0.0001^{*}$ \\
& P. suberosa & mixed & $3.4403^{-06}$ & 0.4298 \\
& P. misera & P. edulis & $3.3563^{-05}$ & $0.0044^{*}$ \\
& P. misera & mixed & $1.3039^{-05}$ & 0.0868 \\
& P. edulis & mixed & $8.2359^{-05}$ & $0.0001^{*}$ \\
\hline Coreid species & between groups & & $1.3805^{-05}$ & 0.0769 \\
& H. clavigera & A. foliacea & $1.3805^{-05}$ & 0.0769 \\
\hline Sex & between groups & $6.2803^{-05}$ & 0.2600 \\
& male & & $6.2803^{-05}$ & 0.2600 \\
\hline Interation & treatment $\mathrm{x}$ coreid species & & $2.8118^{-05}$ & 0.1016 \\
& treatment $\mathrm{x}$ sex & & $7.9394^{-06}$ & 0.7096 \\
& coreid apecies x sex & & $7.4982^{-07}$ & 0.8092 \\
& all variables & $1.9766^{-05}$ & 0.2558 \\
\hline
\end{tabular}

nounced for A. foliacea marginella than for H. clavigera. The latter used fruits of $P$. suberosa more intensively, followed by $P$. misera. Both coreids fed on the vegetative parts of $P$. edulis more frequently than on $P$. suberosa or P. misera (Figure 4).

Focal observations on feeding activity for the mixed treatment indicated that both coreid species used several plant species and parts (Tables 3 and 4). This pattern was more significant for the last instar nymphs, whose feeding activity and instar duration lasted longer.

\section{Discussion}

P. suberosa provides the superior performance for both $H$. clavigera and A. foliacea marginella than
P. misera, $P$. edulis, or all passion vines in combination. This may be explained because $P$. suberosa is a native plant whose wild form is maintained, and is not modified for economic purposes. Moreover, $P$. suberosa is the most abundant passion vine in the area (C. Mondin and GRP. Moreira, UFRGS, unpublished data), and presents both vegetative and reproductive structures throughout the year. In contrast, $P$. misera, the second best host, is heavily defoliated, and presents no reproductive structures during fall and winter (Rodrigues and Moreira, 2004). Field and laboratory observations indicate that these insects do not undergo diapause, remaining active throughout fall and winter. In addition, preliminary data indicate that $H$. clavigera immatures do not reach the forth instar when fed with only one structure of $P$. suberosa, either vegeta- 

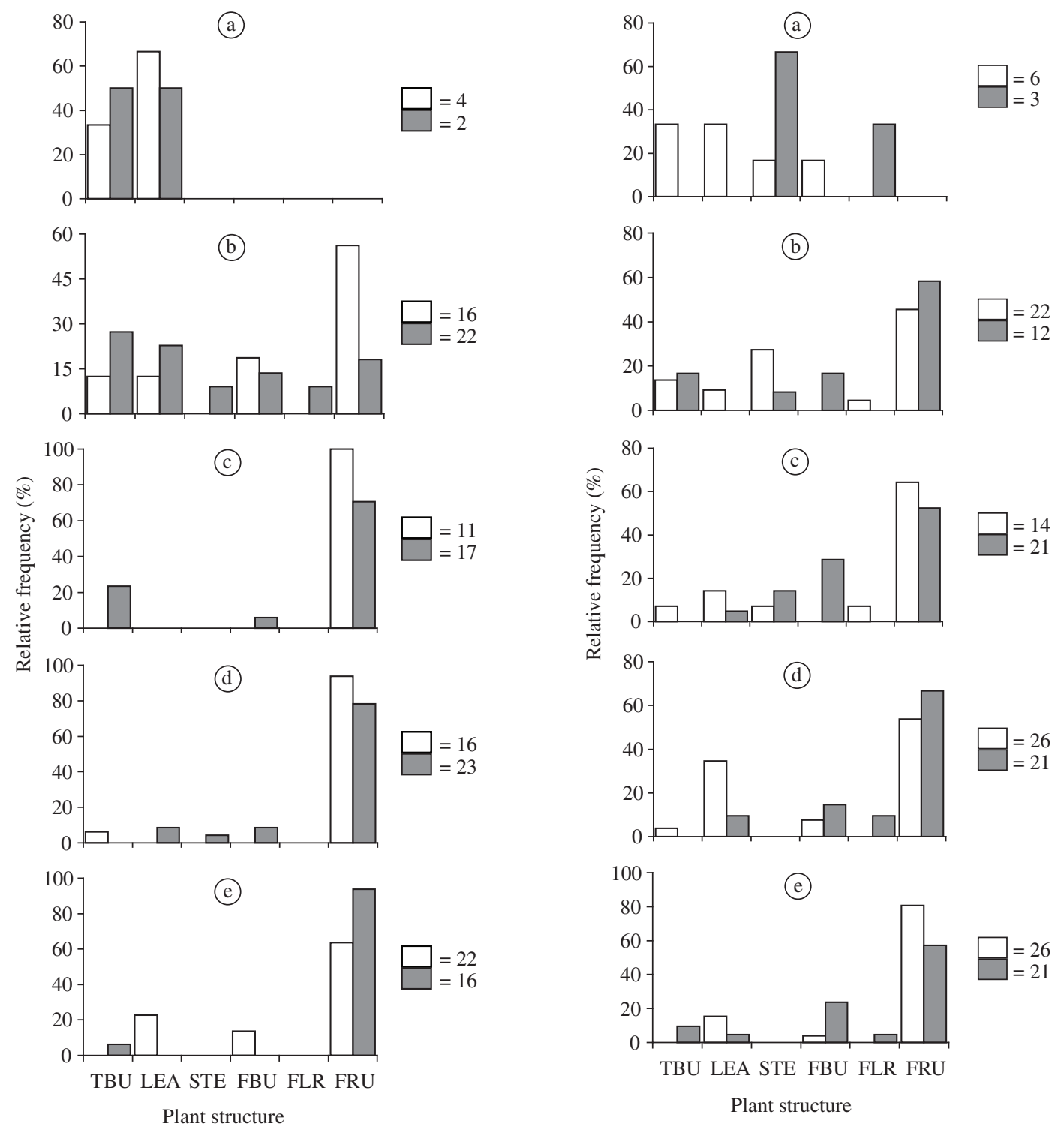

Plant structure

Figure 2. Feeding activity of $H$. clavigera (open bars) and A. foliacea marginella (closed bars) immatures (Figures a to $\mathrm{e}$ - first to fifth instar, respectively) in relation to P. suberosa plant parts. Arabic numbers following the corresponding squares represent number of individuals observed in a given instar. TBU, terminal bud; LEA, leaf; STE, stem; FBU, flower bud; FLR, flower; FRU, fruit.

tive or reproductive (D. Rodrigues and GRP. Moreira, UFRGS, unpublished data). Therefore, the presence of both vegetative and reproductive structures, in all seasons, is an important attribute of a potential host-plant for both coreids.

H. clavigera and A. foliacea marginella females and males show similar performances, indicating that they are affected and respond equally to all passion vines tested. Although females had wider abdomens than males, they are similar in length. Thus, our findings give support to

the hypothesis for the existence of batesian mimicry for both sexes of $H$. clavigera in relation to ichneumonids (Rodrigues, 2003), despite the common size dimorphism for coreids (Schuh and Slater, 1995).

Survivorship was not affected by treatment and coreid species, being less than $50 \%$ in all cases. This value is considered lower than that found in other studies regarding heteropterans (Panizzi et al., 1996). Adopted methodological procedures, such as the absence of soil and/or shoot sectioning may have lead either to nutrition- 

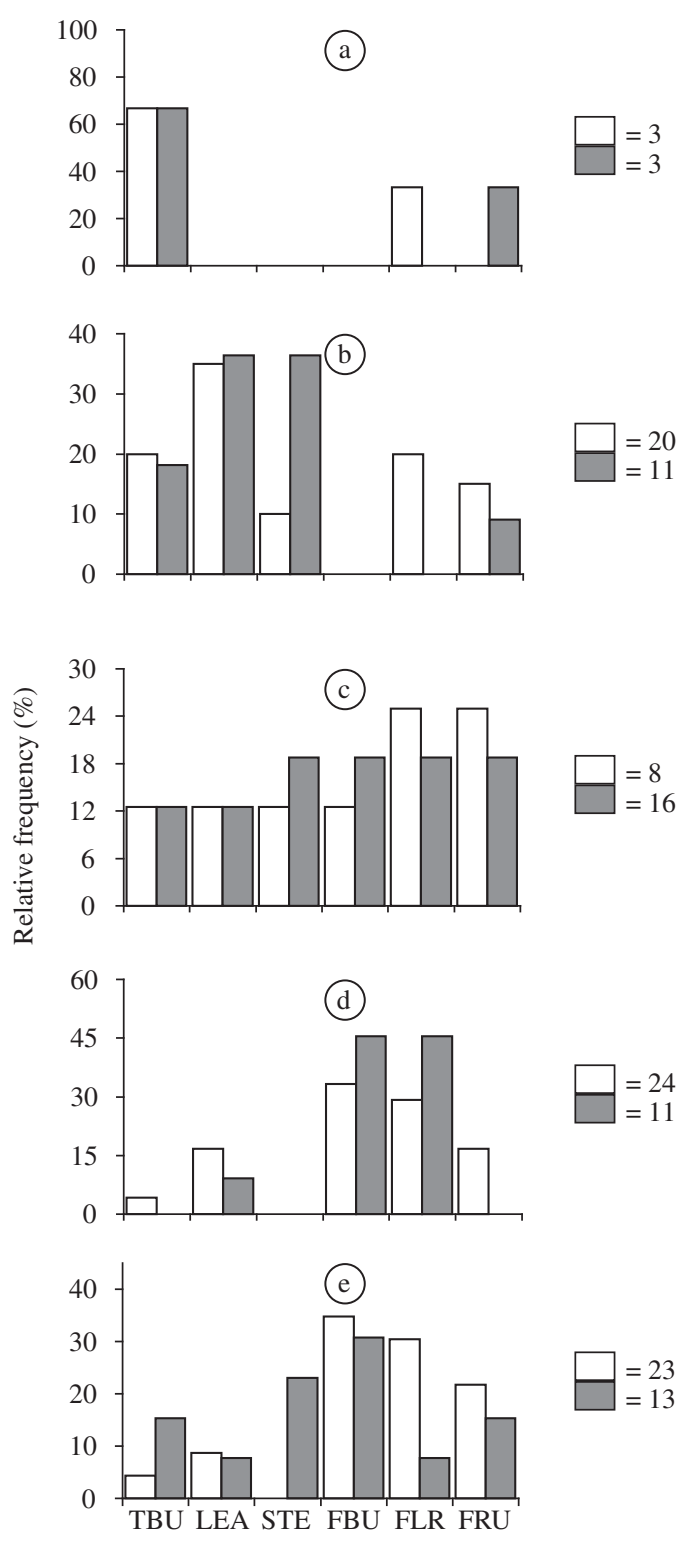

Plant structure

Figure 4. Feeding activity of $H$. clavigera (open bars) and A. foliacea marginella (closed bars) immatures (Figures a to e - first to fifth instar, respectively) in relation to P. edulis plant parts. Arabic numbers following the corresponding squares represent number of individuals observed in a given instar. TBU, terminal bud; LEA, leaf; STE, stem; FBU, flower bud; FLR, flower; FRU, fruit.

al losses or the increase of induced defenses to herbivory, which may explain the high mortality. Such hypotheses, however, need further investigation.

Both $H$. clavigera and A. foliacea marginella feed on reproductive structures of the wild native species ( $P$. suberosa and $P$. misera) more often than on the cultivated one, $P$. edulis. This fact may be related to physi- cal and chemical characteristics of the passion vines. For instance, the fruit is less coriaceous in the wild species. Moreover, all fruit parts of $P$. suberosa and P. misera may be used, including the seeds, due to the length of the stylets (total range: 1.7 to $11.5 \mathrm{~mm}$; Rodrigues and Moreira, 2005) that reach them. According to Sacco (1980) and Acioli (1999), P. suberosa and P. misera fruit diameters range from 0.4 to $1.5 \mathrm{~cm}$. This is not the case of $P$. edulis, whose fruits have a diameter from 5 to $6 \mathrm{~cm}$ (Sacco, 1980), which makes the seed use limited. The fact that seeds are the most nutritive resource for seedsucking insects (Slansky-Júnior and Panizzi, 1987) explains the poorest performance of both species on this host-plant. The relation between stylet size and seed location in Heteroptera is poorly investigated, although host race radiation cases related to that have been reported for some hemipterans (Carrol and Boyd, 1992).

In relation to host-plant chemical defenses, cianogenic glycosides have been described and isolated in purple fruits of $P$. edulis, and already detected in fruits of other cultivated passion vines species (Chassagne and Crouzet, 1998). H. clavigera and A. foliacea marginella may use the vegetative tissues of $P$. edulis more frequently than the reproductive ones to sequester, synthesize or transform secondary metabolites (see Bowers, 1990). Such compounds may be more concentrated in vegetative structures of cultivated plants due to their high palatability and strong susceptibility (MS. Singer, Wesleyan Universtiy, personal communication). This hypothesis, however, must be tested, since these hemipterans apparently use repugnatory glands for defense, whose compound is mainly formed from alcohols, aldehyds, and esters (see Whitman et al., 1990).

The individual feeding pattern observed in the mixed treatment suggests that nymphs use different tissues and different host-plants throughout ontogeny, even within a given instar. This corroborates a food mixing condition (Singer and Bernays, 2003) of these immatures, since several heteropterans are polyphagous. The anisocelins studied here are considered oligophagous (use of host-plants that belong to the same family; Bernays and Chapman, 1994). However, this should be taken with caution, because this classification does not take into account the variety of plant parts explored by them. Besides, H. clavigera and A. foliacea marginella showed good performances when reared in the mixed treatment. The high mobility of nymphs that can easily reach several parts of their host-plants, which enables them to balance nutritional needs as well as contact with toxins, may explain the advantages of having a mixed diet. In addition, although not tested, we did not identify any evidence for the existence of the oviposition site selection regarding the different plant parts. Both in the field and in the laboratory, eggs are rarely found on plants, being laid either isolated or aggregated on several structures such as dry stems and tendrils, cage walls, and others. It is known that the correlation between the oviposition preference and offspring performance is mediated by 
Table 3. Focal observations on the feeding activity of $H$. clavigera immatures in the mixed treatment. Each line represents observations of a given individual at different occasions. FBU. flower bud; GFR. green fruit; LEA. leaf; NEC. extra-floral nectary; PFR. purple fruit; TBU. terminal bud.

\begin{tabular}{|c|c|c|c|c|}
\hline \multicolumn{5}{|c|}{ Instar } \\
\hline I & II & III & IV & $\mathbf{V}$ \\
\hline \multirow[t]{8}{*}{ P. misera LEA } & P. misera GFR & & & \\
\hline & P. misera GFR & & P. edulis GFR & \\
\hline & & P. suberosa GFR & P. misera PFR & $\begin{array}{l}\text { P. misera } \mathrm{GFR} \\
\text { P. suberosa } \mathrm{GFR}\end{array}$ \\
\hline & & & $\begin{array}{l}\text { P. misera } \mathrm{LEA} \\
\text { P. misera GFR } \\
\text { P. edulis NEC }\end{array}$ & \\
\hline & & & P. misera LEA & P. edulis LEA \\
\hline & & & P. misera TBU & $\begin{array}{l}\text { P. misera } \mathrm{PFR} \\
\text { P. edulis } \mathrm{FBU} \\
\text { P. misera } \mathrm{GFR}\end{array}$ \\
\hline & & & & $\begin{array}{l}\text { P. edulis LEA } \\
\text { P. misera FBU }\end{array}$ \\
\hline & & & & $\begin{array}{l}\text { P. misera } \mathrm{LEA} \\
\text { P. misera } \mathrm{LEA}\end{array}$ \\
\hline
\end{tabular}

Table 4. Focal observations on the feeding activity of A. foliacea marginella immatures in the mixed treatment. Each line represents observations of a given individual at different occasions. FBU. flower bud; FLR. flower; GFR. green fruit; LEA. leaf; PFR. purple fruit; TEN. tendril.

\begin{tabular}{|c|c|c|c|c|}
\hline \multicolumn{5}{|c|}{ Instar } \\
\hline I & II & III & IV & $\mathbf{V}$ \\
\hline P. edulis TEN & & & P. misera GFR & \\
\hline P. edulis TEN & & & P. misera GFR & \\
\hline & P. misera FBU & & P. misera FBU & P. misera FBU \\
\hline & P. suberosa LEA & & P. misera FBU & \\
\hline & & P. misera FBU & $\begin{array}{l}\text { P. misera GFR } \\
\text { P. suberosa } \mathrm{GFR}\end{array}$ & \\
\hline & & & P. suberosa GRF & $\begin{array}{l}\text { P. misera } \mathrm{FBU} \\
\text { P. misera } \mathrm{FBU}\end{array}$ \\
\hline & & & P. misera $\mathrm{BFU}$ & P. suberosa GFR \\
\hline & & $\begin{array}{l}\text { P. suberosa GFR } \\
\text { P. suberosa GFR }\end{array}$ & & P. misera PFR \\
\hline & & & & $\begin{array}{l}\text { P. suberosa } \mathrm{GFR} \\
P \text {. suberosa } \mathrm{GFR} \\
\text { P. suberosa } \mathrm{GFR}\end{array}$ \\
\hline & & & $\begin{array}{l}\text { P. misera } \mathrm{GFR} \\
\text { P. misera } \mathrm{GFR} \\
\text { P. misera } \mathrm{GFR} \\
\text { P. suberosa } \mathrm{GFR}\end{array}$ & \\
\hline & & & & $\begin{array}{l}\text { P. edulis FLR } \\
\text { P. edulis FBU }\end{array}$ \\
\hline
\end{tabular}

both genetic and environmental factors, and may explain aspects related to the evolution of insects- plant interaction (Abrahamson and Weis, 1997). However, individuals reared in the mixed treatment did not have a superior performance than other treatments, a pattern already characterized for some generalist insects, including het- eropterans (Bernays and Minkenberg, 1997). In general, H. clavigera and A. foliacea marginella use the green fruits more intensively than other plant parts. In fact, they prefer green fruits (Rodrigues, Soares and Moreira, in prep.), a pattern already described for several sucking species (see Panizzi, 2000). When in contact with leaves, 
they use xylem (Rodrigues et al., submitted), a nutritionally poor, but important resource.

A general statement about hemipteran feeding, not corroborated in this study, points out that first instar nymphs do not feed (e.g., Simmons and Yeargan, 1988), including Holymenia histrio (Baldin and Boiça-Júnior, 1999). Feeding activity on vegetative structures at this instar was only recorded for Leptoglossus fulvicornis, a genus closely related to Anisoscelis (Wheeler-Júnior and Miller, 1990), as well as for Anasa tristis, a coreid that feeds on cucurbits (Bonjour et al., 1991).

There is not a clear relation regarding the hemipteran use of native, non-native, wild or cultivated plants and performance. For example, Neomegalotomus parvus nymphs and adults that use legumes show better performances when fed on cultivated, non-native plants (Santos and Panizzi, 1998). However, the better performance on wild native plants has been recorded for some pentatomid species (Panizzi, 1997). This study indicates a superior performance on wild, native plants than on cultivated ones. In addition, preliminary data showed that $H$. clavigera and A. foliacea marginella young nymphs had a high mortality when reared on $P$. alata shoots, whose reproductive structures had high abscission rates after cutting. Field studies carried out on southeastern Brazil detected a small density of $H$. histrio and $A$. foliacea marginella individuals on the cultivated passion vines $P$. alata and P. edulis (Caetano et al., 2000). Our conclusions regarding the poorest performances of these coreids on these species, in association to a multiple use of plant parts, may question their pest status.

In conclusion, this study suggests an ecological similarity of these sucking species with respect to the interaction with their host-plants, in addition to the strong morphological similarity of the immature stages (Rodrigues and Moreira, 2005). Although belonging to different genus, these coreids may have evolved as sister species due to the reasons mentioned above. Alternatively, the immature stages may present evolutionary convergence or be mimics, in order to maintain the coexistence and the common use of their host plants. Finally, genetic drift is an alternative scenario for explaining $H$. clavigera and A. foliacea marginella evolution.

Acknowledgments - We would like to thank Michael S. Singer (Wesleyan University) for discussions concerning food mixing behavior. We are especially grateful to Antônio R. Panizzi (EMBRAPA/CNPSoja) for critically reading the manuscript. Financial support came from a CAPES Scholarship (Ph.D. Dissertation) granted to Daniela Rodrigues. This is contribution number 480 of the Departamento de Zoologia of Universidade Federal do Rio Grande do Sul.

\section{References}

ABRAHAMSON, WG. and WEIS, AE., 1997. Evolutionary ecology across three trophic levels: goldenrods, gallmakers, and natural enemies. Princeton University Press, Princeton, 456p.

ACIOLI, MF., 1999. Estudo preliminar da biologia floral de Passiflora suberosa Linnaeus (Passifloraceae). Honors Thesis, UFRGS, Porto Alegre, 23p.
AMARAL-FILHO, BF., 1981. Efeito das dietas naturais e de fatores ambientais na biologia de Phthia picta (Drury, 1770) sob condições de laboratório (Hemiptera, Coreidae). Rev. Brasil. Biol., vol. 41, p. 845-853.

AMARAL-FILHO, BF., 1986. Observações sobre o ciclo biológico de Crinocerus sanctus (Fabricius, 1775) (Hemiptera; Coreidae) sob condições de laboratório. An. Soc. Entomol. Brasil, vol. 15, p. 5-18.

AMARAL-FILHO, BF. and CAJUEIRO, IVM., 1977. Observações sobre o ciclo biológico de Veneza stigma (Herbst, 1784) Osuna, 1975 (Hemiptera, Coreidae) em laboratório. An. Soc. Entomol. Brasil, vol. 6, p. 164-172.

AMARAL-FILHO, BF. and STORTI-FILHO, A., 1976. Estudos biológicos sobre Leptoglossus gonagra (Fabricius, 1975), (Coreidae, Hemiptera) em laboratório. An. Soc. Entomol. Brasil, vol 5, p. 130-137.

BALDIN, ELL. and BOIÇA-JÚNIOR, AL., 1999. Desenvolvimento de Holhymenia histrio (Fabr.) (Hemiptera: Coreidae) em frutos de cinco genótipos de maracujazeiro (Passiflora spp.). An. Soc. Entomol. Brasil, vol. 28, p. 421-427.

BERNAYS, EA. and CHAPMAN, RF., 1994. Host-plant selection by phytophagous insects. Chapman and Hall, New York, 312p.

BERNAYS, EA. and GRAHAM, M., 1988. On the evolution of host specificity in phytophagous arthropods. Ecology, vol. 69, p. 886-892.

BERNAYS, EA. and MINKENBERG, PJM., 1997. Insect herbivores: different reasons for being a generalist. Ecology, vol. 78, p. 1157-1169.

BONJOUR, EL. and FARGO, WS., 1989. Host effects on the survival and development of Anasa tristis (Heteroptera: Coreidae). Environ. Entomol., vol. 18, p. 1083-1085.

BONJOUR, EL., FARGO, WS., WEBSTER, JA., RICHARDSON, PE. and BRUSEWITZ, GH., 1991. Probing behavior comparisons of squash bugs (Heteroptera: Coreidae) on cucurbit hosts. Environ. Entomol., vol. 20, p. 143-149.

BOWERS, MD., 1990. Recycling plant natural products for insect defense. In EVANS, DL. and SCHMIDT, JO. (eds.): Insect Defenses. State University of New York Press, Albany, p. 353-386.

CAETANO, AC., BOIÇA-JÚNIOR., AL. and RUGGIERO, C., 2000. Avaliação da ocorrência sazonal de percevejos em cinco espécies de maracujazeiro, utilizando dois métodos de amostragem. Bragantia, vol. 59, p. 45-51.

CARROLL, SP. and BOYD, C., 1992. Host race radiation in the soapberry bug: natural history with the history. Evolution, vol. 46, p. 1052-1069.

CHASSAGNE, D. and CROUZET, JA., 1998. cyanogenic glycoside from Passiflora edulis fruits. Phytochemistry, vol. 49, p. 757-759.

JOSHI, A. and THOMPSON, JN., 1995. Trade-offs and the evolution of host specialization. Evol. Ecol., vol. 9, p. 82-92.

LIMA, AC., 1940. Insetos do Brasil: Hemípteros. Tomo II. Escola Nacional de Agronomia, Rio de Janeiro, 351p.

MANLY, BFJ., 1991. Randomization and Monte Carlo methods in biology. Chapman and Hall, New York, $281 \mathrm{p}$.

MOTULSKY, H., 1999. Analyzing data with Graph Pad Prism software. Graph Pad Software, San Diego, 397p. 
PANIZZI, AR., 1989. Desempenho de ninfas e adultos de Leptoglossus zonatus (Dallas, 1852) (Hemiptera: Coreidae) em diferentes alimentos. An. Soc. Entomol. Brasil, vol. 18, p. 375-389.

PANIZZI, AR., 1997. Wild hosts of pentatomids: ecological significance and role in their pest status on crops. Annu. Rev. Entomol., vol. 42, p. 99-122.

PANIZZI, AR., 2000. Suboptimal nutrition and feeding behavior of hemipterans on less preferred plant food sources. An. Soc. Entomol. Brasil, vol. 29, p. 1-12.

PANIZZI, AR, VIVAN, LM., CORRÊA-FERREIRA, BS. and FOERSTER, LA., 1996. Performance of southern green stink bug (Heteroptera: Pentatomidae) nymphs and adults on a novel food plant (japanese privet) and other hosts. Ann. Entomol. Soc. Am., vol. 89, p. 822-827.

PILLAR, VD., 2001. MULTIV - Multivariate Exploratory Analysis and Randomization Testing. User's Guide, v. 2.1.1.

RODRIGUES, D., 2003. Descrição, trajetórias ontogenéticas de Holymenia clavigera (Herbst, 1784) e Anisoscelis foliacea marginella (Dallas, 1852) (Hemiptera: Coreidae) e interação com três espécies de Passifloraceae. Unpublished Thesis, UFRGS, Porto Alegre, 127p.

RODRIGUES, D. and MOREIRA, GRP., 2004. Seasonal variation in larval host-plants and consequences for Heliconius erato (Lepidoptera: Nymphidae) adult body size. Austral Ecol., vol. 29 , p. 437-445.

RODRIGUES, D. and MOREIRA, GRP., 2005. Comparative description of the immature stages of two very similar leaffooted bugs, Holymenia clavigera (Herbst, 1784) and Anisoscelis foliacea marginella (Dallas, 1852) (Hemiptera: Coreidae). Rev. Bras. Entomol., vol. 49, p. 07-14.

RODRIGUES, D., SANFELICE, D., MONTEIRO, LR. and MOREIRA, GRP., 2005. Ontogenetic trajectories and hind tibia geometric morphometrics of two very similar leaf footed bugs, Holymenia clavigera (Herbst) and Anisoscelis foliacea marginella (Dallas) (Hemiptera: Coreidae). Neotrop. Entomol., vol. 34, no. 5. p. 769-776.

RODRIGUES, D., SAMPAIO, DS., ISAIAS, RMS. and MOREIRA, GRP. Xylem and seed feeding by two passion vine leaf-footed bugs, Holymenia clavigera (Herbst) and Anisoscelis foliacea marginella (Dallas) (Hemiptera: Coreidae), with notes on mouthpart morphology. Ann. Entomol. Soc. Am. submitted.
SACCO, JC., 1980. Passifloráceas. In Reitz, R. (ed.): Flora ilustrada catarinense. Herbário Barbosa Rodrigues, Itajaí, $130 \mathrm{p}$.

SANTOS, CH. and PANIZZI, AR., 1998. Nymph and adult performance of Neomegalotomus parvus (Hemiptera: Alydidae) on wild and cultivated legumes. Ann. Entomol. Soc. Am., vol. 91, p. 445-451.

SCHAEFER, CW. and MITCHELL, PL., 1983. Food plants of the Coreidoidea (Hemiptera: Heteroptera). Ann. Entomol. Soc. Am., vol. 76, p. 591-615.

SCHUH, RT. and SLATER, JA., 1995. True bugs of the world (Hemiptera: Heteroptera): classification and natural history. Cornell University Press, Ithaca, 336p.

SIMMONS, AL. and YEARGAN, KV., 1988. Feeding frequency and feeding duration of the green stink bug (Hemiptera: Pentatomidae) on soybean. J. Econ. Entomol., vol. 81. p. 812-81.

SINGER, MS. and BERNAYS, EA., 2003. Understanding omnivory needs a behavioral perspective. Ecology, vol. 84, p. 2532-2537.

SINGER, MS., RODRIGUES, D., STIREMAN III, JO. and CARRIÈRE, Y., 2004. Roles of food quality and enemy freespace in host use by a generalist insect herbivore. Ecology, vol. 85 , p. $2747-2753$.

SLANSKY-JÚNIOR, F. and PANIZZI, AR., 1987. Nutritional ecology of seed-sucking insects. In: F. Slansky Jr. and J. G. Rodriguez (eds.), Nutritional ecology of insects, mites, spiders, and related invertebrates. John Wiley \& Sons, New York, p. 283-320.

SOKAL, RR. and ROHLF, FJ., 1995. Biometry. $3^{\text {rd }}$ ed. Freeman, New York, 887p.

THOMPSON, JN., 1988. Evolutionary ecology of the relationship between oviposition preference and performance of offspring in phytophagous insects. Ent. Exp. Appl., vol. 47, p. 3-14.

WHEELER-JÚNIOR, AG. and MILLER, GL., 1990. Leptoglossus fulvicornis (Heteroptera: Coreidae), a specialist on magnolia fruits: seasonal history, habitats, and descriptions of immatures stages. Ann. Entomol. Soc. Am., vol. 83, p. 753-765.

WHITMAN, DW., BLUM, WS. and ALSOP, DW., 1990. Allomones: chemicals for defense. In: EVANS DL. and SCHMIDT JO. (eds.), Insect defenses. State University of New York Press, Albany, p. 289-351. 